\title{
Levels of Popularity of Greeting Customs in Vietnamese Culture and the Reflection of Hofstede's Cultural Dimensions
}

\author{
Phan Ngoc Son and Le Tan Cuong
}

\begin{abstract}
Greeting customs in Vietnamese culture embrace a lot of interesting cultural values to discover. Having good understanding of the customs in this developing country is of great help for different fields including cultural studies, business relations, tourisms and education. Those social etiquettes have greatly developed over the past decades and undoubtedly play important roles in the social life of the people living in the country. Although there have been a considerable number of work addressing this area, the majority of them are in the native language which is Vietnamese rather than English or other widely used languages. Besides, there has been little work discussing the most common greeting customs which are currently being used in the social life of Vietnamese people. That explains why greeting customs in this culture remain unfamiliar to outsiders and considerably limit the introduction of the national cultural values to the world. The current paper, therefore, aims to fill in the gap by analyzing levels of popularity of the most common greeting customs in Vietnamese culture and discussing how Hofstede's five cultural dimensions are reflected. A meta-analysis method is implemented in the study to analyze fifteen samples of research including one master thesis, two textbooks, five reports and seven published journal articles. The result reveals levels of popularity of the six common ways of greeting in Vietnamese culture. It also proves the full reflection of Hofstede's cultural dimensions in greeting customs of the investigated culture
\end{abstract}

Index Terms-Vietnamese greetings, greeting culture in Viet Nam, Viet Nam culture, Vietnamese customs.

\section{INTRODUCTION}

A greeting is an indispensable part of most conversations in Viet Nam. When getting involved in a daily conversation, Vietnamese people always show their politeness through various ways of greeting. Without these traditional etiquettes, communication between two Vietnamese people may seriously be influenced and the interlocutors are normally considered to be impolite. Greeting customs in Vietnamese culture are, therefore, among the most interesting topics in the studies of language, culture and communication. Although many aspects of the society in Viet Nam have considerably developed over the last few decades, the values and customs of greetings in Vietnamese culture remains unchanged as expressed in the Vietnamese proverb "Loi chao cao hon mam co" (a greeting is more valuable than a well-prepared meal) [1]. The quote shows that Vietnamese people highly respect the spiritual values rather than the

Manuscript received September 29, 2016; revised November 23, 2016.

Phan Ngoc Son and Le Tan Cuong are with the Dong Nai Technology University, Viet Nam (e-mail: tancuong008@gmail.com).. material ones. Because of this, when a child begins to learn to speak Vietnamese, one of his very first lessons is to learn how to politely greet others, especially the older ones.

Having well awareness of the importance of greeting customs in Vietnamese culture and the necessity of learning more about these cultural aspects, the current paper aims to clarify the most common greeting customs in Vietnamese culture and discuss how they reflect Hofstede's five cultural dimensions. The author firstly starts with a literature review of Hofstede's cultural dimensions and the introduction of Vietnamese culture. He then analyzes the most common greeting customs in the culture. This part is then followed by the section of how greeting customs in Vietnamese culture reflect Hofstede's five cultural dimensions. Finally, the paper comes to a conclusion indicating the popularity of the six most common greeting customs in Vietnamese culture and their full reflection of Hofstede's five cultural dimensions.

\section{LITERATURE REVIEW}

\section{A. Hofstede's Five Cultural Dimensions and Their Validity}

Geert Hofstede is Professor Emeritus of Organizational Anthropology and International Management, University of Maastricht, the Netherlands [2]. He originally worked in IBM where he discovered that although all employees coming from different countries and regions were supposed to follow a complete set of corporate culture, their cultures varied a lot even within one company [3]. The scholar, then, decided to conduct a survey among 116000 members of IBM within more than 40 countries to explore the differences in their thinking and social action [4]. Based on the data collected, the author systematically analyzed and proposed the model of four primary cultural dimensions including power distance, individualism, masculinity and uncertainty avoidance. While Hofstede first used only the 40 largest countries in the study and afterwards extended the analysis to 50 countries and 3 regions, the number of countries and regions were taken into consideration was 74 in the editions of his work since 2001 [3]. The second investigation was partly based on the author's replications and extensions of the IBM study on different international populations. Minkov and Hofstede [5] state that the recent expansion and update of Hofstede's doctrine is indebted to the original groundbreaking work of the 1970s yet a key strength of Hofstede's work has been its ability to adapt and remain progressive. The father of the dimensions added the fifth dimension after he conducted an additional international 
study with a survey instrument developed with Chinese employees and managers (see Table I.). The fifth one, based on Confucian dynamism, is Long-Term Orientation (LTO) and was applied to 23 countries.

TABLE I: HOFSTEDE's FIVE CULTURAL DIMENSIONS

\begin{tabular}{|c|c|}
\hline Dimensions & Definitions \\
\hline Power Distance Index (PDI) & $\begin{array}{l}\text { PDI is the extent to which the less powerful members of organizations and institutions } \\
\text { (like the family) accept and expect that power is distributed unequally. This presents } \\
\text { inequality (more versus less), but defined from below, not from above. It suggests that a } \\
\text { society's level of inequality is endorsed by the followers as much as by the leaders. }\end{array}$ \\
\hline Uncertainty Avoidance Index (UAI) & $\begin{array}{l}\text { UAI deals with a society's tolerance for uncertainty and ambiguity; It ultimately refers to } \\
\text { man's search for Truth. It indicates to what extent a culture programs its members to feel } \\
\text { either uncomfortable or comfortable in unstructured situations. }\end{array}$ \\
\hline $\begin{array}{c}\text { Individualism } \\
\text { (IDV) } \\
\text { Individualism vs. Collectivism }\end{array}$ & $\begin{array}{l}\text { IDV on the one side versus its opposite, collectivism, that is the degree to which } \\
\text { individuals are integrated into groups. The word "collectivism" in this sense has no } \\
\text { political meaning: It refers to the group, not to the state. }\end{array}$ \\
\hline $\begin{array}{c}\text { Masculinity (MAS) } \\
\text { Masculinity vs. femininity }\end{array}$ & $\begin{array}{l}\text { MAS versus its opposite femininity, refers to the distribution of roles between the } \\
\text { genders which is another fundamental issue of any society to which a range of solutions } \\
\text { are found. The assertive pole has been called "masculine" and the modest, caring pole } \\
\text { "feminine" }\end{array}$ \\
\hline $\begin{array}{l}\text { Long-Term Orientation (LTO) } \\
\text { Long-Term Orientation and short-term } \\
\text { Orientation }\end{array}$ & $\begin{array}{l}\text { LTO versus short-term orientation. It can be said to deal with Virtue regardless of Truth. } \\
\text { Values associated with Long Term Orientation are thrift and perseverance; values } \\
\text { associated with Short Term Orientation are respect for tradition, fulfilling social } \\
\text { obligations, and protecting one's "face". Both the positively and negatively rated values } \\
\text { of this dimension are found in the teachings of Confucius, the most influential Chinese } \\
\text { philosopher who lived around } 500 \text { B.C. ; However, the dimension also applies to } \\
\text { countries with a Confucian heritage. }\end{array}$ \\
\hline
\end{tabular}

Since it was first introduced in the 1970s, the doctrine has always been the valid framework for a great number of cultural studies. The cultural dimensions have been used in different fields and proven their validity. De Mooij and Hofstede [6] state that the dimensions are applied to understand differences in consumer behavior across countries. In a recent study, these authors further mention the application of Hofstede's cultural dimensions in various areas of global branding and advertising, and the underlying theories of consumer behavior [7]. In addition, the framework is used in international strategic management [8].

Over the past decades, although Hofstede's work has always been a paradigm in the field of cross cultural studies all over the world, it remains controversial [4], [9]-[11]. Minkov and Hofstede [12] point out that in spite of the great interest in Hofstede's dimensions of national culture, some of the dimensions have not been replicated with nationally representative samples. Additionally, the dimensions are reported to help in understanding cultural differences, but they cannot describe the whole culture [13]. Chan and Cheung [13] also criticized the samples of the study. They insisted that as Hofstede collected data from respondents who all worked in the same corporate culture, the respondents might not be representative of the broader national population [13]. Clearly, the reliability and validity of these cultural dimensions have been questioned by a considerable number of researchers.

Together with a number of criticizing perspectives, Hofstede's framework has received great consensus of many scholars. Froholdt and Knudsen [14] point out that Hofstede is undoubtedly the most famous and most cited researcher in the domain of cross-cultural study of organization. Hofstede's framework, according to Blodgett, Bakir and Rose [15], has provided the theoretical foundation upon which much cross-cultural research has been based. It is widely used in different areas of research for understanding culture [16]. Moreover, it has been reported to be applied in a wide variety of contexts, across most (if not all) of the behavioral science disciplines [15].

As the pervasive influence of Hofstede's work across the academic community, it would be reasonable to assume that the validity of the cultural framework has been fully established [15].

\section{A. Vietnamese Culture and the Role of Greetings}

Viet Nam has a diverse and complex culture as the country has experienced different oversea cultural values over its long history. The culture has been framed by the Chinese' with the impact of Confucianism and Taoism; by Hindu culture with its Buddhist diffusion; and recently influenced by the west with the coming of Christianity and the acceptance of Western thought [17][18][19][20]. Around 4000 years ago, groups of people in the northern Red River Delta grew rice, which then led to a system of irrigation and an ordered society called the kingdom of Van Lang [21]. According to Guillain [21], this is an area where Chinese emperors controlled for 1000 years. Within this long period, different aspects of Vietnamese culture were little by little influenced by the Chinese. 
In term of morality, Confucian values such as respect for hierarchy, order, and rules, an appreciation for learning, a sense of decorum and a regard for sincerity, courage and perseverance were in a long period imparted in Viet communities [22] and have become part of Vietnamese cultural values. Interestingly, those whose performance is against the values are regarded to be also against Vietnamese culture. Additionally, when it comes to religions in the country, Taoism, Buddhism, and Confucianism over many centuries have been known to become intertwined, simplified, and Vietnamized to constitute Vietnamese folk religion shared to some extent by all Vietnamese people. Moreover, Guides [23] indicates that 60 percent of Vietnamese words in the national language originally have their roots in the Chinese language which is the result of over a thousand year of colonization and cultural transfer.

\begin{tabular}{|c|c|c|c|c|}
\hline No. & Tittle & Year & Source & Type of material \\
\hline 1 & $\begin{array}{l}\text { Hanh vi chao hoi cua nguoi viet va he thong } \\
\text { bai tap day hanh vi chao hoi cho hoc sinh tieu } \\
\text { hoc }\end{array}$ & 2009 & [30] & Thesis \\
\hline 2 & Modern Vietnamese & 2009 & [42] & Textbook \\
\hline 3 & Study Vietnamese language & 2010 & [32] & Textbook \\
\hline 4 & Greetings in Viet Nam and in English & 2011 & [31] & Report \\
\hline 5 & English and Vietnamese greetings & 2011 & [37] & Report \\
\hline 6 & $\begin{array}{l}\text { Dac trung ngon ngu- van hoa cua hanh vi chao } \\
\text { hoi trong tieng Anh va tieng Viet }\end{array}$ & 2011 & [36] & Report \\
\hline 7 & Greetings around the world & 2002 & [43] & Report \\
\hline 8 & Loi chao cua nguoi Viet & No year & [38] & Report \\
\hline 9 & The Vietnamese language learning framework & 2001 & [44] & Journal article \\
\hline 10 & Patterns of polite expressions in Vietnamese & 2009 & [39] & Journal article \\
\hline 11 & $\begin{array}{l}\text { Tim hieu loi noi va nghi thuc giao tiep cua } \\
\text { nguoi nam bo qua tieu thuyet cua Ho Bieu } \\
\text { Chanh }\end{array}$ & 2014 & [1] & Journal article \\
\hline 12 & $\begin{array}{l}\text { The role of greetings in expressing Vietnamese } \\
\text { culture in communication }\end{array}$ & 2012 & [25] & Journal article \\
\hline 13 & Loi chao trong van hoa doi song nguoi Viet & 2011 & [45] & Journal article \\
\hline 14 & $\begin{array}{l}\text { Greetings and matter of compiling } \\
\text { Vietnamese textbooks }\end{array}$ & 2013 & [40] & Journal article \\
\hline 15 & $\begin{array}{l}\text { A study on Vietnamese greetings and } \\
\text { compared on French greetings }\end{array}$ & 2008 & [24] & Journal article \\
\hline
\end{tabular}

TABLE III: FREQUENCY OF INVESTIGATED GREETINGS CUSTOMS

\begin{tabular}{|l|c|c|c|}
\hline & & Frequency & Percent \\
\hline Greeting customs & Greeting by saying "chao" & 14 & 93.3 \\
& Greeting by making questions & 11 & 73.3 \\
Greeting by using exclamations & 7 & 46.7 \\
Greeting by congratulating & 5 & 33.3 \\
Greeting by inviting & 6 & 40.0 \\
Greeting by praising or having comments & 5 & 33.3 \\
\hline
\end{tabular}

Besides, during the French colonial period starting from 1883 [21], Vietnamese culture absorbed various influences and the two most important of which are the spread of Catholicism and the adoption of the Latin alphabet. A great number of churches and other ecclesiastical buildings were built all over the country, especially in big cities. All of Viet Nam was officially made part of a French protectorate, opposing French rule [21]. Therefore, students at all levels were mostly supposed to go to Catholic schools. During that time, the national language was formed using the Latin 
alphabet.

In addition, in the socialist era, Vietnamese culture has been deeply influenced by government-controlled media and the cultural influences of socialist programs. For many decades, foreign cultural influences from the Soviet Union, China, Cuba and others communist countries have one way or another influenced on Vietnamese culture.

In the setting of a diverse culture like in Viet Nam, a greeting plays an important role in evaluating human manners; it is one of the most important aspects in cultural life of each nation [24]. A greeting as showed in Vietnamese dictionary is an activity saying or showing respect or formality [25]. It is seen as a respectful 'gift' that can help to facilitate social interaction [26]. It is a compulsory requirement setting foundation for the start of a conversation in Vietnamese culture [25]. As can be seen, the role of greetings in Vietnamese culture is firmly established and finding out the most common greeting customs in this country is a worthy thing.

\section{A. Research Questions}

As Vietnamese people are widely known to use the word "chao" when greeting others in communication, the author of this paper wonders if there are any other ways to express greetings in the country and levels of popularity of them. Therefore, he comes up with the two following research questions:

1) How are the levels of popularity of the most common greeting customs in Vietnamese culture?

2) How do greeting customs in Vietnamese culture reflect Hofstede's five cultural dimensions?

\section{THE STUDY}

\section{A. Study Samples}

In the study, fifteen samples of research are investigated. The samples include one master thesis, two textbooks, five reports and seven published journal articles (see Table II). Among them, seven samples are written in English and the rest is in Vietnamese. Although the number of the study samples is limited, many things are interestingly revealed.

\section{B. Methodology and Data Analysis}

In the study, a meta-analysis method is systematically implemented to examine levels of popularity of six common greeting customs. Table II shows the frequency of each of the customs found in the fifteen samples of research.

\section{Greeting by Using the Word "Chao"}

Vietnamese people use various ways to greet one another in communication [27]. The greetings not only embrace the speakers' messages but also their emotions [28]. This is a kind of greeting that the speaker directly uses the words or phrases having the verb "chao" (greet). It is formed by combining the verb "chao" and the name or the title of the listeners in the conversation [28]-[32]. As showed in Table III, greeting by using the word "chao" is found in fourteen out of fifteen samples account for $93.3 \%$ of the investigated samples, which means this is the most common greeting custom in Vietnamese culture.
In Viet Nam, if A wants to greet B, he normally says "Chao B". That is, "chao" goes with the name of the listener which is known as B in this case. In addition to using "chao" together with the listener's first name, Vietnamese people also prefer to use both pronouns and professional tittles. Them [27] states that pronouns are mainly used in greetings in other languages, but Vietnamese people use both pronouns and kinship words such as anh (brother), chi-em (sister); ong (grandfather), ba (grandmother), bac (uncle), co (aunt), di (aunt), chu (uncle)- chau, con... and professional tittles such as thay (teacher, for male), co (teacher, for female), bac si (doctor), ong cai, ong ly, ong huyen, ong doi...in their greetings. These kinships and professional tittles even outperform pronouns [27]. This is for one listener.

Similarly, for more than two listeners, the speaker may use "chao cac ban", "Chao mung quy vi", "Kinh chao cac ong ba". These phrases can be used differently depending on different situations, but they all can be simply understood that "Distinguished guests". In America, the greeting in the same situations can be expressed "Ladies and gentlemen". As can be seen, while Vietnamese can use "Chao" flexibly with "the name or the title of someone" to form a greeting like "Chao ....", Americans use only one or limited phrases to express the formal greeting. By this way, Vietnamese greetings customs are more diversified and special than that of American. In term of address, Vietnamese language has various forms of address based on age, sex, and marriage status. Therefore, Vietnamese people often use this kind of greeting in formal conversations when they wish to show their respect to different listeners at different age, sex and marital status.

\section{Greeting by Making Questions}

Like other Asian societies, Vietnam is considered as a "high-context society" [33]. Vietnamese society actually emphasizes modesty and humility as well as harmonious relations with others [33]. Furthermore, respect is another key factor in the Vietnamese value system [19]. That explains why they normally try to avoid conflicts and sensitive subjects are mostly approached in an indirect way. In high context culture like in Vietnam, a lot of implicit meanings can be found in what is said as the speakers use a shared code concentrating on group orientations and stressing nonverbal communication [34].

In communication, Vietnamese people prefer indirect greetings. Greeting by making questions, then, is among these kinds of indirect activities which are more complicated and expresses very high-context meaning. The speaker in this situation indirectly greets the listeners using different types of informal questions [28], [30], [31]. He does not use any verbs like "chao" (greet). The speaker when using this kind of greeting can ask questions as a way of saying hello to the listeners.

For a very informal conversation between two friends or even two strangers, a Vietnamese can get started by asking one or some of the following questions:

- Chi di dau day? (Where are you going to?)

- Bac dang lam gi day? (What are you doing?)

- Khoe khong? (How are you?)

- Dao nay cong viec the nao? (How are things?) 
- Que ban o dau? (Where are you from?)

As can be seen, the questions are very specific, but the speakers do not really mean to exploit the information from the listeners. The questions here are only for greeting purposes and in many situations the listeners do not have to answer what the speakers asks about. This kind of greeting only shows the speakers' care to the listeners. We know that Vietnam is considered a fairly collectivist culture [35]. People in this country pay much attention to others' lives. They are always willing to share and to be shared happiness and sadness in their lives. That is why this kind of greeting can be found everywhere in Viet Nam. It has become an indispensable part in many Vietnamese people's daily lives. As can be found in Table III, eleven samples mention greeting by making questions as a way to greet in Vietnamese culture, equivalent to $73.3 \%$ in the total of the investigated samples. Clearly, this greeting custom is in the second place among the most common greeting customs in Viet Nam.

Every day, when a Vietnamese sees his family members, his neighbors, his co-workers or someone that he knows, he frequently uses this kind of greeting. Depending on the relationships between the speaker and the listeners, he/ she may use various questions to show his/her greetings. All of the questions used in this kind of greeting are considered as a means to help Vietnamese deliver their greetings to the listeners. In America, using questions is also a way to say "hello" to others. The questions used in the Americans" conversations are, however, more general than those in Viet Nam. Moreover, it can be impolite if the speaker asks about personal information in America. Clearly, the content of the greetings can be the same in the two cultures, but the ways that Americans use to express their greetings are much different from those in Viet Nam. By this way, indirect greeting using questions in Vietnamese community really shows its specialties.

\section{E. Greeting by Using Exclamations}

In the reality of communication, besides greeting directly using "Chao" and greeting indirectly using questions, Vietnamese people also make exclamations to show their greetings [25], [30], [31], [36]-[39]. Using an exclamation is another special aspect of indirect greetings. In this country, exclamations are frequently used to show speakers' emotions when they are happy, sad, surprised or disappointed. Among them, exclamations are used to greet others in communication [29]. This kind of greeting is definitely unique in the world. Table III shows that this greeting custom makes up $46.7 \%$ of frequency in the total samples investigated ( 7 out of 15 samples). That is, the greeting custom is also among the common ones, but it is in the third place.

In the daily life, a Vietnamese may say "O, Bac Ba" (oh, uncle Ba), "A, Mẹ" (ah, Mom), "Troi ơi, Anh Hai" (oh god, Mr Hai)... All of these exclamations are used to show the speaker's emotion when meeting the listeners. This is a kind of one-way communication because after making such an exclamation, the speaker may go on asking a question or saying something to interact with the listeners without waiting for their responses. Clearly, the exclamations are made to warm up the conversation and the listeners in this situation can feel that the speakers have greeted them. A greeting, by this way, is indirectly expressed in the conversation.

\section{F. Greeting by Inviting}

Greeting by inviting is also known as a common way of greeting among many people in Viet Nam [30], [31], [36]-[39]. For Vietnamese, inviting a guest to have dinner when the guest accidentally visits a family dinner is considered as a way to express the greeting. For example, a Vietnamese may say "Moi bac vao dung com" (come in and have lunch with us!). This phrase is used as a greeting as well as an invitation for dinner. The guest in this situation can either accept or refuse. However, in the reality, the listeners traditionally refuse by saying the phrase "Vang, cam on bac" (thank you) or "Vang, moi nguoi cu tu nhien" (be yourself, everyone!). In fifteen samples of this study, six authors consider inviting as a common way of greeting in Vietnamese culture (See Table III). This kind of greeting is proven to be not quite popular, but it is a particular aspect of indirect greetings and occupies the fourth position among the common greeting customs in Viet Nam.

\section{G. Greeting by Congratulating}

Greeting by congratulating is getting popular in Viet Nam nowadays [30], [31], [36]-[38]. Greeting in such a way is original from English- speaking and western countries. For example, "Nice day", "Have a good trip" and "good night" are well known in the USA, England and Australia. Those phrases are used to show the speakers' greetings to the listeners. Greeting in this way was unfamiliar to most Vietnamese people in the past. However, over the last few decades, the number of Vietnamese who can use English is rapidly increasing. This leads to the fact that they use the similar phrases in Vietnamese to congratulate others as an indirect way of greeting. As can be seen in Table III, this greeting custom is presented in five out of fifteen samples of research in the study. Although, the number of people using those phrases in Viet Nam is limited in comparison with other kinds of greeting customs, this way of greeting is in the fifth place of the common greeting customs and considered as an important part in many conversations.

\section{H. Greeting by Praising or Giving Comments}

"Dep doi qua!" (Nice couple!) is an example of greeting by praising or giving comments. In Viet Nam, due to their care for the surrounding people, they often pay much attention to the appearance of their friends, co-workers, neighbors...Therefore, whenever they find something new from others, they normally praise or give comments. A Vietnamese may say "Dep doi qua" (Nice couple) when they meet a friend handing out with his girlfriend. This is one way to show their greeting to the listeners and a way to attract the listeners as well. The listeners in this situation obviously would feel happy to hear such a praise or comment. Greeting by praising or giving comments is widely used in American, but this purpose of these two activities is different from that in Viet Nam. Americans tend to praise and give comments much more than Vietnamese people, but they do because they really want to show their emotion, not because they want to greet someone. In the contrary, Vietnamese people praise or 
give comments as a way to say "hello" to others [30], [31], [36]-[38]. In the current study, greeting by praising or giving comments is found in five samples (33.3\% of the total). Depending on different listeners, praising or giving comments can be varied to use as a greeting in Viet Nam community. Together with greeting by congratulating, greeting by praising or giving comments is in the fifth place in the common greeting customs in the culture.

\section{DISCUSSION}

\section{A. Levels of Popularity of Six Common Greeting Customs in Viet Nam}

The specialty of Vietnamese culture is that people in the country nationalize what they learn from the outside world to maintain and develop their cultural values [41]. Vietnamese greeting customs were formed a long time ago and have been an important part of Vietnamese culture and communication. The significance of greetings appears to keep remained in contemporary Vietnam [26].

Over the past few decades, foreigners have witnessed a lot of improvement in the way Vietnamese greet others. This improvement is an obvious thing in the context of today globalization. Since Viet Nam joined WTO, people in this country have had more opportunities to better their understanding about the outside world. When working with foreign counterparts, it is necessary for Vietnamese people to know the cultures where their partners come from to make sure that the communication between them can be possible. Little by little, Vietnamese people realize that there are many interesting things in the way people greet others that can be applied in their daily lives and started using them as a new way in greeting customs. On the other hand, in the process of using traditional greeting customs, they realize that something has been out of date and they decide to remove them from their greeting customs. Although the ways that Vietnamese greets nowadays are a little bit different from that in the past, its meanings are somehow the same.

In the current study, fifteen samples of research analyzed using a meta-analysis enable the author to reveal the levels of popularity of the six most common greeting customs in Vietnamese culture (see Table IV).

TABLE IV: THE POPULARITY OF THE GREETING CUSTOMS

\begin{tabular}{|c|l|}
\hline $\begin{array}{c}\text { Levels of } \\
\text { popularity }\end{array}$ & \\
\hline $1^{\text {st }}$ & Greeting by saying "chao" Greeting customs \\
\hline $2^{\text {nd }}$ & Greeting by making questions \\
\hline $3^{\text {rd }}$ & Greeting by using exclamations \\
\hline $4^{\text {th }}$ & Greeting by inviting \\
\hline $5^{\text {th }}$ & Greeting by congratulating and greeting by praising and giving comments \\
\hline
\end{tabular}

Besides, it is important to consider the tendency of greeting customs in Vietnamese culture. Nowadays, Vietnamese people living in big cities are different from those living in the countryside in many ways. Greeting customs are also among these differences. This leads to the fact that there are two main trends in greeting in Viet Nam. The first trend comes from the ones who have good jobs with high salary in big cities. They live in dynamic environments and can learn a lot of the modern world including new ways to impressively greet others. In daily communication, many of them do not greet others using the traditional greeting customs. For example, when using indirect greetings, they also make questions to greet others, but the topics they discuss seem to be more complicated. These people prefer talking about health, jobs, fashion, entertainment or future plans. They may ask "cong viec sao roi?" (How is your business?) instead of asking some simple questions like "Bac di dau day?" (Where are you going?). The other trend comes from the people living in the countryside. For these people, everything seems to be opposite. They do not work in dynamic environments, so they do not have many opportunities to learn new things from the outside world. Many of them still use traditional greeting customs in greeting. Of course, some of them have improved their ways of greeting, but in comparison with those in the cities, the improvement is not considerable. Clearly, different living conditions offers people different thinking about how to greet others and the two trends in Vietnamese greeting customs are predictable.

\section{A. The Full Reflection of Hofstede' Five Cultural Dimensions}

Hofstede is famous for his cultural dimensions. This is because these dimensions are the most important aspects of a culture. That is why they are considered as a framework commonly used to evaluate a cultural characteristic in a particular culture. In Viet Nam greeting customs, Hofstede's five cultural dimensions are fully reflected.

Firstly, Viet Nam is considered as a collectivist culture [35]. This originally comes from Vietnamese's Confucian roots. During thousand years of building and safeguarding the country, Vietnamese always had to work together to struggle against foreign invaders. Without their solidarity, they would not have won many battles. The fact gradually formed the ideal among people in this country that community is very important and everyone in the community must think of themselves as a whole rather than individuals. Failing to do this obviously results failures. Because of this ideal, Viet Nam culture has been strongly orientated around family and community. This aspect plays in a crucial role in the performance of Vietnamese greeting customs. Unlike Americans, Vietnamese people like spending time greeting and chatting with others. They consider this is a way to show 
their hospitality and connect themselves with the community. Therefore, whatever greeting customs a Vietnamese performs, he or she normally thinks of others. Vietnamese greeting customs, by this way, clearly show the collectivism of Viet Nam culture, which means Hofstede's third dimension known as Individualism is valid.

Secondly, Vietnam culture is a Low Uncertainty Avoidance one [35]. Although people in Viet Nam have suffered a lot from many wars from foreign invaders like China, France and the USA, they choose not to dwell on this. After the national reform in 1986, not so long after the end of the anti-American war, Viet Nam welcomed outsiders to come to invest in Viet Nam. Up to now, Viet Nam has been a good friend of most of the countries all over the world. Vietnamese people are confident in their country and comfortable with the uncertainty that tomorrow brings. This makes Vietnamese people feel comfortable to learn new things in general and new greeting customs in particular from foreign cultures. That is why Vietnamese greeting customs nowadays are getting richer and richer. The customs show that Vietnamese people forgot the past and search for Truth, Fairness and equality heading to the future. They expect a better future being beside friends coming from other countries in the world. Thanks to this, it is clear that there is the existence of Hofstede's second dimension which is Uncertainty Avoidance Index in Vietnamese greeting customs.

Thirdly, like many other eastern countries, Vietnam has a high power distance. The power in Vietnam is not equally distributed but this is accepted as part of the culture from all ends of the social classes. This high power distance is showed in the ways they greet others. For example, in a formal meeting in Viet Nam, the MC is supposed to take turn introducing the important guests. He may say "Kinh thua ong A?, kinh thua ong B, kinh thua ong C" (Dear, Mr A, Mr B, $\mathrm{Mr} \mathrm{C}$ ). Without doing such an activity, it is considered to be impolite. However, in the same meeting in America or many other low-power- distance countries, the MC may just say "Ladies and Gentlemen" to welcome all participants. This shows that everyone in America is considered equal. No one is more important than others. One more example can be found in many daily conversations in Viet Nam, people often say "Chao ong", "Chao chu", "Chao anh". All these greetings are for the same gender, but the verb "Chao" (greet) goes with different pronouns such as: "ong” (Mr.), "chu” (uncle) and "anh" (brother). If the conversation is in America, the speaker may just use the pronoun "you" to indicate all of them. Clearly, the example shows that in Viet Nam power distance is high and everyone is not equal in term of power.

Another thing is to the distribution of roles between the genders in Vietnamese greeting customs, which indicates the existence of Masculinity. While the listeners both male and female ones in many English-speaking countries are commonly addressed as "you" in communication, they seem to be more complicated in Viet Nam. In reality, Vietnamese people clearly distinguish the two genders in communication. They use ong, chu, bac, cau for males and ba, co, di, chi, em for females. Moreover, Vietnamese people put greater emphasize on the role of male than female ones. For instance, when meeting his grandparents, a grandson is supposed to greet his grandfather first and then his grandmother. This clearly shows that greeting customs in Viet Nam highly appreciate the roles of males in communication and reflect the validity of Hofstede's dimension of Masculinity.

Finally, Vietnam is considered high on long-term orientation [35]. They highly value the relationships they build, not the results they get right away. When a Vietnamese greets someone, he wants to show that he would like to develop and maintain the relationship. They do not greet because they want to show their politeness. When coming across an old friend, a Vietnamese would greet to show that he does care his friend and want his friend to understand that he appreciates the relationship between them. It is clear that Vietnamese greeting customs are high on long-term orientation.

Hofstede's five cultural dimensions are proven valid and widely acknowledged in the field of cultural studies all over the world. In this paper, the five dimensions are also easily found in the Vietnamese greeting customs. This clearly shows that Hofstede's five cultural dimensions are fully reflected in the investigated cultural greeting customs.

\section{CONCLUSION}

Vietnamese greetings are very important in Viet Nam modern and traditional culture. In this paper, levels of popularity of the six common Vietnamese greeting customs and the reflection of Hofstede's five cultural dimensions are discussed. The data collected shows that together with saying "chao" to greet, Vietnamese people use five other greeting customs in their communication. The paper presents different levels of popularity of the six common greeting customs and also discusses in what ways Vietnamese greeting customs reflect Hostede's five cultural dimensions, which sheds light on the validity of Hofstede's cultural framework in a diverse culture of a developing country like Viet Nam. However, as "Vietnamese greeting customs" is a broad aspect and limited work has been done before, it is challenging to collect data to do a meta analysis. Hopefully, further research using a larger number of study samples may help reveal more insights on the issue of greeting customs in Vietnamese culture and especially on the full reflection of Hostede's cultural dimensions in Vietnamese culture.

\section{REFERENCES}

[1] H.T. L. Phuong and N. V. No, "Tim hieu loi noi va nghi thuc giao tiep cua nguoi nam bo qua tieu thuyet cua Ho Bieu Chanh," Khoa Hoc Xa Hoi, vol. 12, no. 196, pp. 29-39, 2014.

[2] G. Hofstede, "Dimensionalizing cultures: The hofstede model in context," Online Readings in Psychology and Culture, vol. 2, no. 1, 2011.

[3] X. Shi and J. Wang, "Interpreting hofstede model and globe model: Which way to go for cross-cultural research?" International Journal of Business and Management, vol. 6, no. 5, 2011

[4] H. Khastar, R. Kalhorian, G. A. Khalouei, and M. Maleki, "Levels of analysis and hofstede's theory of cultural differences: The place of ethnic culture in organizations," International Conference on Financial Management and Economics, vol. 11, pp. 320-323, 2011.

[5] M. Minkov and G. Hofstede, "The evolution of Hofstede's doctrine," Cross Cultural Management: An International Journal, vol. 18, no. 1, pp. 10-20, 2011. 
[6] D. M. Mooij and G. Hofstede, "Convergence and divergence in consumer behavior: implications for international retailing," Journal of retailing, vol. 78, no. 1, pp. 61-69, 2002.

[7] D. M. Mooij and G. Hofstede, "The Hofstede model: Applications to global branding and advertising strategy and research," International Journal of Advertising, vol. 29, no. 1, pp. 85-110, 2010.

[8] S. Beugelsdijk, R. Maseland, and A. Hoorn, "Are scores on Hofstede's dimensions of national culture stable over time? A cohort analysis," Global Strategy Journal, vol. 5, no. 3, pp. 223-240, 2015.

[9] E. B. Bergiel, B. J. Bergiel, and J. W. Upson, "Revisiting Hofstede's dimensions: Examining the cultural convergence of the united states and Japan," American Journal of Management, vol. 12, no. 1, 2012.

[10] B. McSweeney, "Hofstede's model of national cultural differences and their consequences: A triumph of faith-a failure of analysis," Human relations, vol. 55, no. 1, pp. 89-118, 2002.

[11] M. Wu, "Hofstede's cultural dimensions 30 years later: A study of Taiwan and the United States," Intercultural Communication Studies, vol.15, no. 1, 33, 2006.

[12] M. Minkov and G. Hofstede, "A replication of Hofstede's uncertainty avoidance dimension across nationally representative samples from Europe," International Journal of Cross Cultural Management, vol. 14, no. 2, pp. 161-171, 2014.

[13] A. W. Chan and H. Y. Cheung, "Cultural dimensions, ethical sensitivity, and corporate governance," Journal of Business Ethics, vol. 110, no. 1, pp. 45-59, 2012.

[14] L. L. Froholdt and F. Knudsen, "The human element in maritime accidents and disasters-A matter of communication," in Proc. the International Maritime English Conference on Maritime Lecturers' Association (IMLA), pp. 9-12, 2007.

[15] J. G. Blodgett, A. Bakir, and G. M. Rose, "A test of the validity of Hofstede's cultural framework," Journal of Consumer Marketing, vol. 25, no. 6, pp. 339-349, 2008.

[16] G. Hofstede, "Culture's consequences: Comparing values, behaviors, institutions, and organizations across nations," Beverly Hills, CA: Sage Publication, 2001.

[17] P. C. Hunt, "An introduction to Vietnamese culture for rehabilitation service providers in the United States," Culture and Disability: Providing Culturally Competent Services, pp. 203-223, 2005.

[18] N. K. Kham, An Introduction to Vietnamese Culture, Center for East Asian Cultural Studies, 1967.

[19] T. H. Nguyen, "Vietnam: Cultural background for ESL/EFL teachers," The Review of Vietnamese Studies, vol. 2, no. 1, pp. 1-6, 2002.

[20] L. S. Woods, Vietnam: A global studies handbook. ABC-CLIO, 2002.

[21] C. Guillain, Viet Nam, Raintree, 2012.

[22] G. Murray, Vietnam-Culture Smart!: The Essential Guide to Customs \& Culture. Bravo Limited, 2016.

[23] I. Guides, Insight Guides: Explore Viet Nam, Apa Publications (UK) Limited, 2016

[24] L. N. Hoan, "A study on Vietnamese greetings and compared to French greetings," in Porc. 6th Conference of Students' Scientific Research, 2008 .
[25] M. T. H. Yen and L. T. Huong, "The role of greetings in expressing Vietnamese culture in communication," Ngon Ngu Va Doi Song, vol. 10, no, 204, 2012.

[26] K. Nguyen, "Daily deference rituals and social hierarchy in Vietnam," Asian Social Science, vol. 12, no. 5, 2016.

[27] T. Them, Tim Ve Ban Sac Van Hoa Viet Nam. Ho Chi Minh, 2006.

[28] H. Yen, Dac Trung Ngon Ngu Van Hoa Trong Hanh Vi Chao Hoi NgaAnh-Viet. Da Nang, 2013.

[29] S. Srichampa, "Politeness strategies in Hanoi Vietnamese speech," Mon-Kmer Studies, vol. 34, pp. 137-155, 2003.

[30] V. T. Tram, "Hanh vi chao hoi cua nguoi Viet va he thong bai tap day hanh vi chao hoi cho hoc sinh tieu hoc," 2009.

[31] D. Trang, Greetings in Vietnamese and English, Ho Chi Minh University of Education, English, 2011

[32] N. Q. Vinh, Study Vietnamese language, 2010.

[33] V. A. Minh, Aspects of Vietnamese Culture, 2012.

[34] P. T. T. Huong, "How Vietnamese culture influence on learning and teaching english," Online Submission.

[35] Viet Nam. [Online]. Available: http://acad.depauw.edu/ mkfinney/teaching/Com227/culturalportfolio s/VIETNAM/VIETNAM/typologies.html

[36] N. Duong, "Dac trung ngon ngu-Van hoa cua hanh vi chao hoi trong tieng Viet va tieng Anh," 2011.

[37] N. Hang, English and Vietnamese Greetings, 2011.

[38] N. T. Ngan, Loi Chao Cua Nguoi Viet.

[39] S. Srichampa, "Patterns of polite expressions in Vietnamese," Mon-Khmer Studies, vol. 38, pp. 117-147, 2009

[40] V. Thi, Greetings and Matters of Compliling, Ngon ngu \& Doi song, 2013.

[41] V. Khieu, "Truyen thong va doi moi trong van hoa Viet Nam," Xa Hoi Hoc, vol. 3, 1988 .

[42] P. Giuong, Modern Vietnamese, van hoa-van nghe Tp. HCM, 2009.

[43] D. Wile, Greetings Around the World, 2002.

[44] B. N. Ngo and B. H. Tran, "The Vietnamese language learning framework, “ Journal of Southeast Asian Language Teaching, vol. 10, pp. 1-24, 2001.

[45] N. T.Thuy, Loi Chao Trong Doi Song Van Hoa nguoi Viet, 2011.

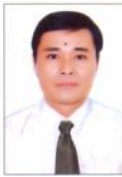

Phan Ngoc Son is director of Dong Nai Technology University, Viet Nam. He is a doctor in business administration. He is interested in researching business, educational management and culture.

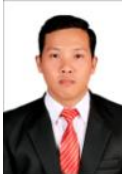

Le Tan Cuong is a vice dean of Faculty of Foreign Languages, Dong Nai Technology University, Viet Nam. He is a mater holder in Tesol. His research interests include teaching methods, educational management and cultural studies. 